\title{
ENTOMOLOGY
}

\section{Bee diversity in fragmented areas of Volcano Etna (Sicily, Italy) at different degrees of anthropic disturbance (Hymenoptera: Apoidea, Anthophila)}

\author{
G.F. Turrisi, ${ }^{1}$ S. Bella, ${ }^{2}$ R. Catania, ${ }^{2}$ P. La Greca, ${ }^{3}$ V. Nobile, ${ }^{4}$ V. D’Urso ${ }^{5}$ \\ ${ }^{1}$ Amateur Entomologist, Pedara; ${ }^{2}$ Consiglio per la Ricerca in Agricoltura e l'Analisi dell'Economia Agraria (CREA) - \\ Centro di ricerca Olivicoltura, Frutticoltura e Agrumicoltura, Acireale; ${ }^{3}$ Amateur Entomologist, Catania; ${ }^{4}$ Amateur \\ Entomologist, Ragusa; ${ }^{5}$ Dipartimento di Scienze Biologiche, Geologiche e Ambientali, Sezione di Biologia Animale \\ “Marcello La Greca”, Università di Catania, Italy
}

\begin{abstract}
The present three-year study traces the diversity of four bee communities in fragmented pedemontane areas of Volcano Etna (Catania province, Sicily) near the Metropolitan City of Catania, under different land management regimes. The selected areas comprise two different urban parks within Catania (Parco Gioeni and Parco degli Ulivi), a Nature Reserve (Complesso Immacolatelle e Micio Conti, San Gregorio di Catania), and an agroecosystem (a citrus orchard, Aci Catena). Previous data obtained from a well-investigated area (Leucatia, north of Catania) have been used as a control for bee diversity for this study. The results include an outline of bee species richness,
\end{abstract}

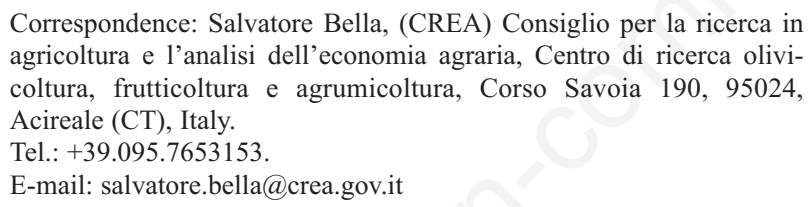
agricoltura e l'analisi dell'economia agraria, Centro di ricerca olivicoltura, frutticoltura e agrumicoltura, Corso Savoia 190, 95024, Acireale (CT), Italy.

Tel.: +39.095.7653153

E-mail: salvatore.bella@crea.gov.it

Key words: Apoidea, bee diversity, environmental fragmentation, urbanization, Etna, Sicily.

Contributions: The authors contributed equally.

Conflict of interest: The authors declare no potential conflict of interest.

Funding: This study was partially funding by "Linea 2 - Pia.ce.ri., progetto BINT".

Availability of data and materials: All data are available within the text.

Received for publication: 13 December 2021.

Accepted for publication: 3 January 2022.

${ }^{\circ}$ Copyright: the Author(s), 2021

Licensee PAGEPress, Italy

Journal of Entomological and Acarological Research 2021; 53:10326 doi:10.4081/jear.2021.10326

This article is distributed under the terms of the Creative Commons Attribution Noncommercial License (by-nc 4.0) which permits any noncommercial use, distribution, and reproduction in any medium, provided the original author(s) and source are credited. data on the composition of bee communities, and seasonal patterns, using several diversity indexes. The study of bee diversity shows a total of 163 species, arranged in five families. The four investigated locations include 104 species arranged in four families: Andrenidae (20 species), Halictidae (15 species), Megachilidae ( 31 species), and Apidae (38 species); with a similar number of species (102) recorded in the control site (Leucatia). The study highlights strong seasonal variations of bee communities in all investigated sites, with differentiated seasonal patterns, whose compositions are affected mainly by forage sources, suitable nesting sites, as well as human activities. The data obtained provide a rough but basilar framework to assess management strategies to maintain adequate levels of bee diversity, especially for those areas with moderate to high environmental fragmentation. Our findings highlight the importance of season-long sampling of bee population factors if used as indicators in ecological studies.

\section{Introduction}

Bees (Hymenoptera, Apoidea, Anthophila) represent the most important pollinator group worldwide and are considered the best indicators of overall species richness in agroecosystems together with the Coleoptera and Heteroptera (Duelli \& Obrist, 1998; Oertli et al., 2005; Westphal et al., 2008), due to their complex life histories, habitats, and specific requirements for nutrition and nesting (Orr et al., 2020). The scientific studies on using bees as indicators of biodiversity or landscape structure have recently increased (Tscharntke et al., 1998; Steffan-Dewenter et al., 2002; Steffan-Dewenter \& Leschke, 2003). Bees need habitats rich in flowering plants, as large proportions of the species only collect pollen from very specific plants (Westrich, 1990; Muiller, 1996; Wcislo \& Cane, 1996). In addition, bees have specific nesting sites, such as dead wood, bare soil, plant stems, or rock fissures. As bees are typical 'central-place foragers', which return to their nests after foraging, feeding and nesting sites must be close to one another, and this represents an important ecological trait affecting local diversity, distribution and abundance (Westrich, 1996; Steffan-Dewenter et al., 2006).

Bees simultaneously represent a mega-diverse taxon that is extremely challenging to sample thoroughly and an important group to understand because of their pollination services (Wilson 
\& Jamieson, 2019). The destruction and fragmentation of their natural habitats and the consequently increasing dominance of heavily anthropogenically disturbed habitats, such as agricultural intensification and urban expansion, have been considered major causes for the large-scale losses of bee biodiversity in the past decades (Romano \& Zullo, 2012). Their decline is a great concern as they provide a critical ecosystem service with their pollination activities (Wilcove et al., 1986; Terayama \& Murata, 1990; Corbet et al., 1991; Matheson et al., 1996; Westrich, 1996; Porrini et al., 1998; Dobson et al., 1999; Hanski, 1999; Robinson \& Sutherland, 2002; Steffan-Dewenter, 2002, 2003; Henle et al., 2004; SteffanDewenter et al., 2006; Brown \& Paxton, 2009; Hernandez et al., 2009; Patiny et al., 2009; Winfree et al., 2009; Le Feon et al., 2010; Wilson \& Jamieson, 2019).

Therefore, a better knowledge of their local diversity, and seasonal ecological patterns over time are crucial for the use of bees as bio-indicators (Oertli et al., 2005; Patiny et al., 2009; Wilson \& Jamieson, 2019), and extensive studies on bee composition in different areas whether natural, semi-natural or anthropogenic are highly needed to establish how environmental transformation affects bee diversity also to evaluate ecological resilience under correct management.

The southeastern slope of Volcano Etna (Eastern Sicily) is currently under a high anthropogenic stress and has experienced dramatic biodiversity loss mainly from habitat destruction, alteration, and fragmentation. These ecological factors in this region and their putative negative effects on its insect communities, especially pollinators, have never been investigated (Turrisi et al., 2006). In the present contribution, the results of a pilot study in various locations around Etna are discussed with three main aims: i) to reconstruct the composition of the bee communities in different selected sites; ii) to determine and compare the main ecological traits of the bee communities; iii) to highlight the ecological aspects affecting the conservation of bee communities in a fragmented context.

\section{Materials and Methods}

\section{The previous studies on faunistic and ecological aspects of bees of Volcano Etna}

The current knowledge of bee diversity of Volcano Etna should not be considered fully satisfactory. There are several scattered faunistic data dispersed in many different specialistic papers and only within the last three decades, some faunistic and taxonomic investigations have been carried out, mainly by Nobile (1987, 1988, 1989, 1990, 1991, 1993a, 1993b, 1994, 1995a, 1995b, 1996, 2001); Nobile \& Turrisi (1997, 1999, 2004, 2013, 2015, 2016); Nobile \& Campadelli (1998); Nobile \& Tomarchio (1998a, 1998b, 2001); Bella et al. (2020). Other studies have focused on ecological aspects, such as trophic relationships with special references to pollination and agro-ecological management (Mazzeo et al. 1999, 2001, 2002, 2004, 2007a, 2007b, 2015, 2019; Longo 2002; Quaranta et al. 2004; Seminara et al. 2009).

\section{Study sites}

The province of Catania, covering about $3500 \mathrm{~km}^{2}$, has two main areas: i) Volcano Etna, itself, and ii) the mountain's foothills which have a wide alluvial plain originating from the sediment deposition of the Simeto River and its tributaries. The study was carried out on Etna's southeastern Pedemontane slope, chosen as it has been strongly affected by human activities due to the presence of a huge and complex urban center and its wide agro-ecological systems. Its extended and diversified road networks introduce a further ecological factor creating significant environmental fragmentation.

The selected sites (Figure 1) were chosen to take into account different habitats, anthropic influences, and differentiated management practices. All investigated sites share three main characteristics: i) they have an area no less than $8.000 \mathrm{~m}^{2}$; ii) they are located in the foothills of Volcano Etna, with altitudes ranging from 100 to $300 \mathrm{~m}$ a.s.1.; iii) they are located in a more or less developed urban network. In detail, we investigated four sites, one agroecosystem, one Nature Reserve, and two urban parks:

1 - AC, Aci Catena (municipality), $225 \mathrm{~m}$ a.s.1., 37³6’28.49”N, 15ㅇ'22.18'"E (Figure 2A).

Agroecosystem. A citrus orchard about 10 hectares in size, organically managed. It is very close to urban areas and is surrounded by fallow cultivated fields. It is characterized mainly by abundant flowering weed plants (e.g., Cyperus rotundus L., Fumaria capreolata L., Galactites tomentosus Moench, Glebionis coronaria (L.) Spach, Malva spp., Oxalis pescaprae L., Poa annua L., Urtica spp.).

2 - SG, Riserva Naturale Integrale "Complesso Immacolatelle e Micio Conti”, 280 m a.s.1., 37³3'43.52”N, 156'53.35”E (Figure 2B).

Nature Reserve. A natural area entirely comprised within the Special Conservation Area (ZSC) ITA070008, of San Gregorio di Catania and Acicastello municipalities. About 68 hectares in size and characterized by relicts of deciduous thermophilous woods filled with Quercus virgiliana (Ten.) Ten., and $Q$.

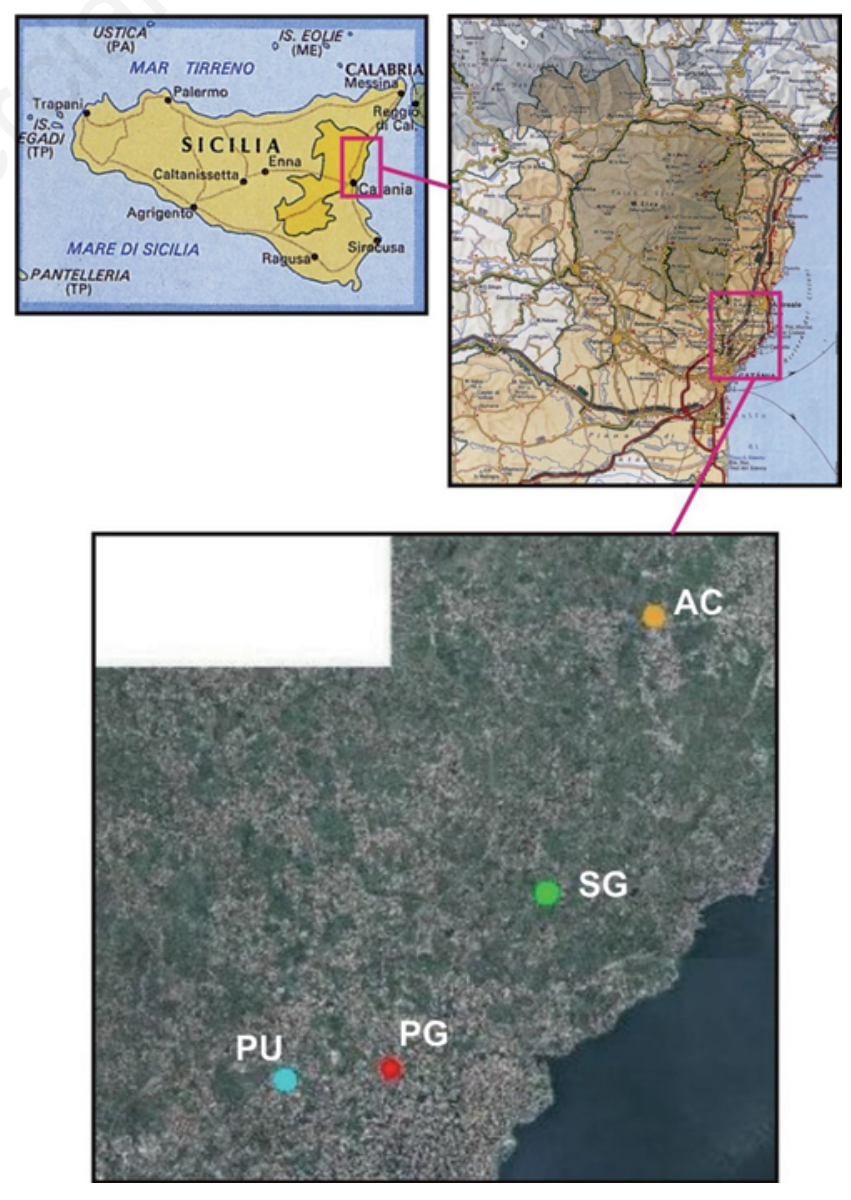

Figure 1. Localisation of the study sites in Eastern Sicily: Volcano Etna southeastern slope (acronyms in the text). 
amplifolia Guss., and broad open areas dominated by Asphodelus cerasiferus J. Gray, Euphorbia dendroides L., Ferula communis L., Olea europea L., Pistacia terebinthus L., and Rhamnus alaternus L.

3 - PG, Parco Gioeni, 120 m a.s.1., 37³1'40.06”N, 154'52.30’'E (Figure 2C).

Central uRban PARK. Entirely comprised within Catania's city limits, it is about 75 hectares in size. It is one of the largest parks in Catania with thermo-mediterranean vegetation and several allochthonous species (Bella \& Musmeci, 2004).

4 - PU, Parco degli Ulivi, $190 \mathrm{~m}$ a.s.1., 37³1'33.14”N, 15³'25.98''E (Figure 2D).

PERIPHERAL URBAN PARK. Located on the outskirts of Catania, about 65 hectares in size. It's located on an abandoned olive orchard and thus comprised of mainly thermo-mediterranean vegetation (Bella \& Musmeci, 2004).

Further data regarding another well-investigated site, LE Timpa di Leucatia, $210 \mathrm{~m}$ a.s.1., 37³2’34.56”N, 155'8.98’E (Figure 2E) were used as a control for this study, based on the irregular but continuous collecting efforts by V. Nobile over a twenty-year period (V. Nobile, unpubl.). The area straddles the northern limits of Catania and the southern limits of Sant'Agata Li Battiati municipalities. The area is characterized by thermomediterranean vegetation and cultivated areas after the post-coltural abandonment of previously citrus and olive orchards. It also holds a relevant water source forming a very short perennial stream with Arundo formations.

The selected sites, based on their geographic position, and their land management could be considered as fragments of wider areas under low to medium-high anthropogenic pressure.

The data presented in this study are part of the results of the
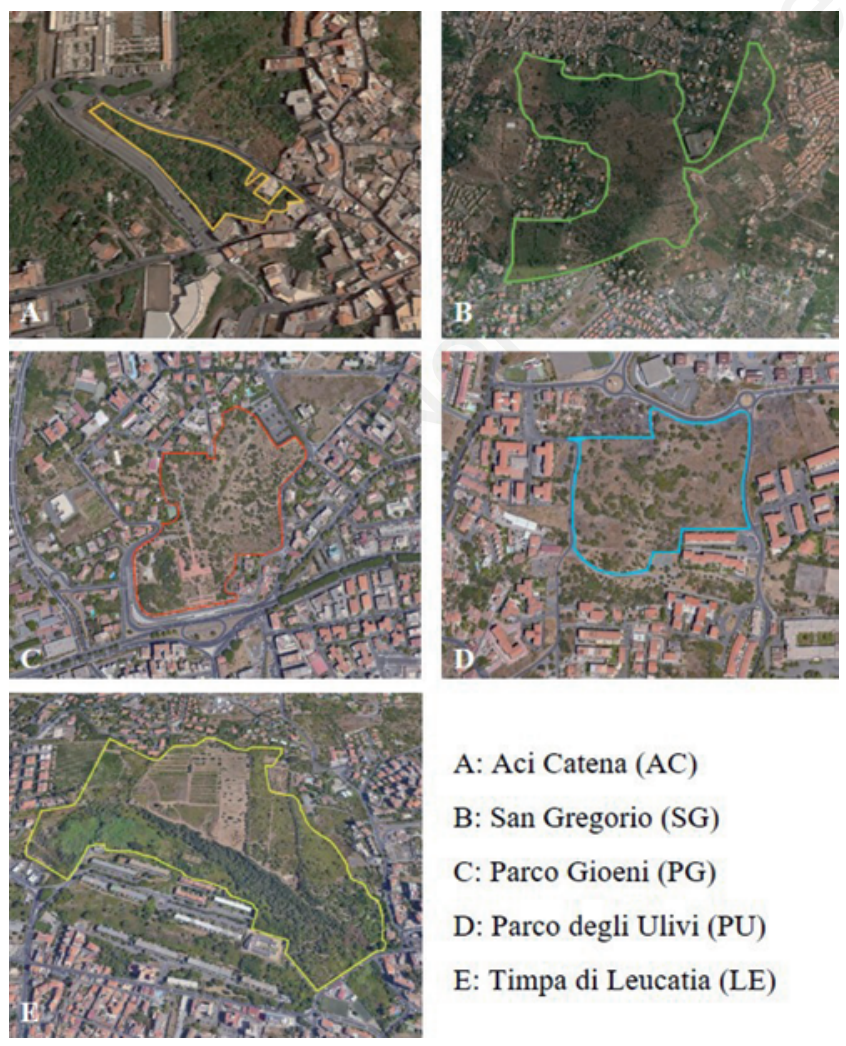
A: Aci Catena (AC)
B: San Gregorio (SG)
C: Parco Gioeni (PG)
D: Parco degli Ulivi (PU)
E: Timpa di Leucatia (LE)

Figure 2 (A-E). Satellite map of the four investigated sites (A-D), and control site $(\mathrm{E})$.
Ph.D. Thesis of P. La Greca, debated on December 2010, University of Catania (La Greca, 2010), with preliminary results presented in La Greca et al. (2011).

\section{Collecting protocol and identification of material}

The study covers a three-year period from February 2007 to February 2010 with an extension covering most of the seasonal activity until the end of October. Sampling followed the standardized protocol suggested by the Italian Project A.M.A. (Ape, Miele, Ambiente) (Quaranta et al., 2004), and was based mainly on selected walking line transects (Banaszak, 1995; Prendergast et al., 2020). Thus, collecting was done by integrating several methods as suggested by Prendergast et al. (2020). The collecting efforts were carried out in the four investigated sites during the same period. Each transect was precisely established to cover the heterogeneity of the site environments with a fixed length of $200 \mathrm{~m}$ and width of $1 \mathrm{~m}$. The transects were visited four times per day, at selected hours covering the almost entity of the sun-filled day, 9:00, 12:00, 15:00, and 18:00 to collect all the seen specimens on flowers (a socalled fixed generic survey). During the field research, the flowering plants were identified, and the observed bees were collected and counted for subsequent registration. Simultaneously, collecting efforts were improved by adopting variable transect walks to integrate the data obtained from standardized transect walks. During the spring, several nesting traps were made of Arundo stems of different diameters and placed in selected habitats within each site. After the summer, each trap was brought to a laboratory under local environmental conditions to obtain the traps' specimens. The material of the present study was identified by V. Nobile based on the most relevant taxonomic literature: Ebmer (1974); Schmid-Egger \& Scheuchl (1997); Scheuchl (2000, 2006). The collections of G.F. Turrisi, V. Nobile and the Department of Biological, Geological and Environmental Sciences, Section of Animal Biology "Marcello La Greca", University of Catania were examined for comparisons. The systematic and nomenclature followed mainly Michener (2007), with some subsequent updates.

\section{Statistical analysis}

The starting point in characterizing the bee community of each selected site came from the creation of a checklist based on the overall identified species. The data obtained throughout the three years for each site were pooled to create robust datasets on bee diversity and phenology as well as the local abundance of the species. For the characterization of the bee communities, we utilized several ecological indexes:

1) The Shannon-Weaver Diversity Index (H'), was used to estimate the bee diversity across each site using the algorithm: $H^{\prime}=-\sum i$ pi $\ln ($ pi), where: H' is the Shannon-Weaver Diversity Index; pi proportion (frequency) of each species in the sample over the total considered; $\ln (\mathrm{pi})$ is the natural logarithm of this proportion. In general, the $\mathrm{H}^{\prime}$ index ranges from 1.5 to 3.5 , and values less than 1.5 are applicable to community with a low species richness and a very low number of dominant species. Whereas values exceeding 3.5 correspond to communities with a high species diversity and similar dominance (Magurran, 2004).

2) Pielou Evenness Index (J'), calculated as: $J^{\prime}=H^{\prime} / \log (S)$, where $\mathrm{H}^{\prime}$ is the Shannon-Weaver Diversity Index and $\log (\mathrm{S})$ is the decimal logarithm of the species number by assuming a similar dominance of the recorded species. The $\mathrm{J}$ ' index is complementary to the previous H' index and shows how the community is homogeneous with regard to abundance. This index varies from 0 to 1 , with values increasing depending on dominance equipartition (Pielou, 1984).

3) Simpson Index (SI), calculated through the algorithm: $1-\lambda=1$ - 
$\left(\sum \mathrm{p}_{\mathrm{i}}^{2}\right)$, where $\mathrm{pi}$ is the proportion of species over the total. This index measures the equipartition within a community, with values ranging from 0 to 1 (Magurran, 2004).

The faunistic similarity was obtained through a simple multivariate analysis (cluster analysis using the Ward Algorithm and neighborjoining based on the Jaccard Algorithm), by using a presence/absence matrix of the species in each site (Hammer et al., 2001).

To characterize nesting behavior, species were divided into three main categories: 1) "endogeic" (EN), nesting in the ground with actively built galleries; 2) "hypergeic" (HY), nesting in a variety of substrates above ground, e.g., rocky walls, vegetal stems; 3 ) "nesting less" (NL), bees with parasitic behavior. These nesting biological divisions are mainly based on Brooks (1988), Vicidomini (1995), Levermann et al. (2000), Pesenko et al. (2000), Michener (2007), Nicoli Aldini (1994, 2007), Intoppa et al. (2009), Terzo \& Rasmont (2011), Erbar \& Leins (2017), and Müller (2019).

To characterize their social behaviour, species were divided into the following categories: 1) "solitary" (SO), females build their own nests and provide it with food for their offspring; 2) "eusocial" (ES), forming temporary colonies with divisions of labor; 3) "pre-social" (PS), nesting separately in the same place, sometimes with rough divisions of labor; 4) "gregarious" (GR), nesting in aggregation without distinct colonies; 5) "social parasitic" (PAS), nesting within a colony of other social species; 6) "cleptoparasitic" (CP), searching for other bee species to place their own eggs. Data on social behavior are mainly based on: Westrich (1990), Nicoli Aldini (1994, 2007), Pesenko et al. (2000), Michener (2007), Intoppa et al. (2009), Erbar \& Leins (2017), and Müller (2019).

Finally, the species were divided based on buccal apparatus length, as follows: 1) short-tongued (S-T) and 2) long-tongued (L$\mathrm{T})$. This morpho-functional trait is relevant for the trophic activity of adults and is determined by directly observing the collected specimens.

\section{Results}

\section{Characterization of bee communities}

Over the three years, a total of 1140 bee specimens were collected in the four selected sites. They belong to 104 species, which is $15.16 \%$ of the 686 species recorded in Sicily (Comba, 2019). The sampled species comprise of four families: Andrenidae (20 species), Halictidae (15 spp.), Megachilidae (31 spp.), and Apidae (38 spp.) (Appendix 1). The species were distributed among the sites as follows: 46 species in the agroecosystem (AC); 63 species in the Nature Reserve (SG); 54 species in the central urban park (PG); and 53 in the peripheral urban park (PU).

The total of 1140 specimens were collected, as follows: 247 in the agroecosystem (AC); 313 in the nature reserve (SG); 354 in the central urban park (PG); and 226 in the peripheral urban park (PU) (Figure 3).

Out of the bee species recorded, 9.61\% were parasitic (CP + PAS). The species collected in all four sites are: Andrena ovatula, Anthophora balneorum, A. crinipes, A. plumipes, Bombus hortorum, B. terrestris calabricus, Eucera caspica, E. eucnemidea, E. nigrescens, Habropoda tarsata, Halictus asperulus, Hoplitis adunca, Megachile parietina, Osmia caerulescens, O. melanogaster, Panurgus siculus and Xylocopa violacea (Appendix 1).

The most represented of the bee families were Apidae, with 566 specimens (49.7\%), and Megachilidae, with 404 specimens (35.4\%). The other families included Andrenidae with 103 specimens (9.0\%), and Halictidae with 67 specimens (5.4\%) (Figure 4).
The genus Eucera was the most represented with 182 specimens: agroecosystem (AC) (50 specimens), nature reserve (SG) (39 specimens), central urban park ( $\mathrm{PG}$ (62 specimens), peripheral urban park (PU) (31 specimens) (Figure 5). The most abundant species in all sites were Eucera nigrescens Pérez, 1879 (Figure 6),

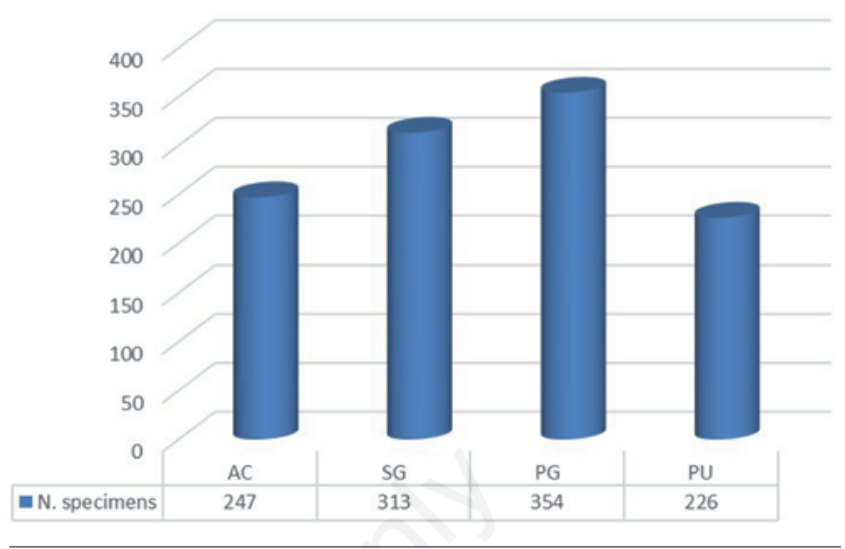

Figure 3. Number of bee specimens collected in the four selected sites.

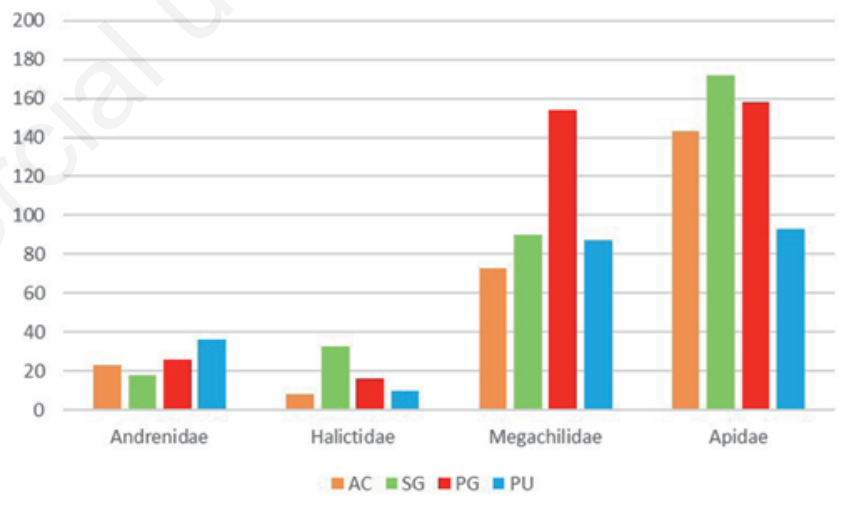

Figure 4. Number of bee specimens, under families, collected in the four selected sites.

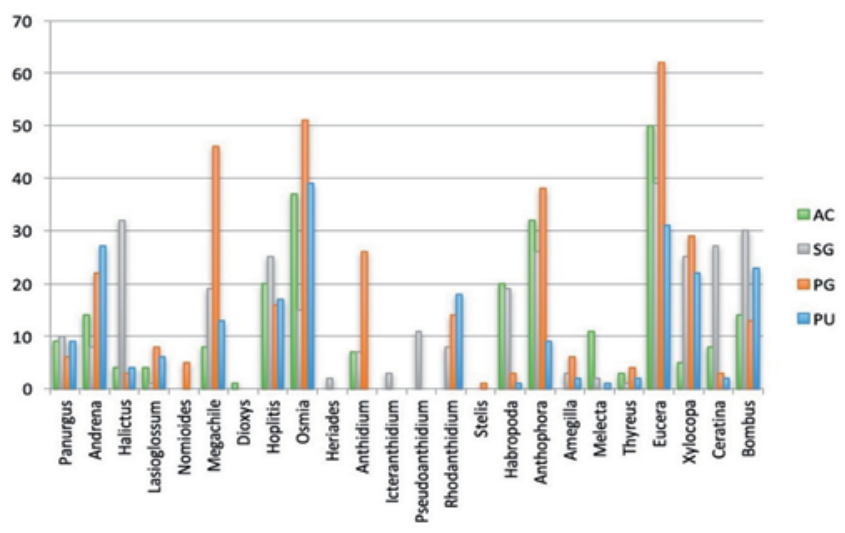

Figure 5. Number of bee specimens, under genera, collected in the four selected sites. 
an hypogeic, polilectic, and long-tongued species, with 38 specimens in the agroecosystem (AC), 28 specimens in the nature reserve (SG), 34 specimens in the central urban park (PG), and 20 in the peripheral urban park (PU).

In the control site in Leucatia (LE), the most speciose genera were Andrena, Halictus, Lasioglossum, Megachile and Osmia (Appendix 1).

The specimens collected in the four investigated sites belong to 24 genera (Figure 6): Amegilla (2 species, 11 specimens), Andrena (19 spp., 71 specimens), Anthidium (1 sp., 40 specimens), Anthophora (7 spp., 105 specimens), Bombus (6 spp., 80 specimens), Ceratina (6 spp., 40 specimens), Dioxys (1 sp., 1 specimen), Eucera (6 spp., 182 specimens), Habropoda (2 spp., 43 specimens), Halictus (9 spp., 32 specimens), Heriades (1 sp., 2 specimens), Hoplitis (5 spp., 78 specimens), Icteranthidium (1 sp., 3 specimens), Lasioglossum (5 spp., 19 specimens), Megachile (5 spp., 86 specimens), Melecta (3 spp., 14 specimens), Nomioides (1 sp., 5 specimens), Osmia (11 spp., 142 specimens), Panurgus (1 sp., 32 specimens), Pseudoanthidium (2 spp., 11 specimens),
Rhodanthidium (2 spp., 40 specimens), Stelis (1 sp., 1 specimen), Thyreus (3 spp., 10 specimens), and Xylocopa (3 spp., 81 specimens). Of these genera, the following 14 are shared by the four investigated sites, the other being restricted to one on more sites: Anthidium, Anthophora, Bombus, Ceratina, Eucera, Habropoda, Halictus, Hoplitis, Lasioglossum, Megachile, Osmia, Panurgus, Thyreus and Xylocopa (Figure 5; Appendix 1).

\section{Comparative analyses of the investigated bee communities}

The quantitative comparison of the four bee communities is presented in Figures 3-5. A total of 46 species were recorded in the agroecosystem (AC): Andrenidae (7 species), Apidae (23 spp.), Halictidae (5 spp.), and Megachilidae (11 spp.) (Figure 7A). A total of 67 species were recorded in the nature reserve (SG) including: Andrenidae (8 species), Apidae (24 spp.), Halictidae (10 spp.), and Megachilidae (21 spp.) (Figure 7B). A total of 54 species were recorded in the central urban park (PG) as follows: Andrenidae (12 species), Apidae (20 spp.), Halictidae (6 spp.), and Megachilidae (16 spp.) (Figure 7C). A total of 53 species were recorded in the periph-
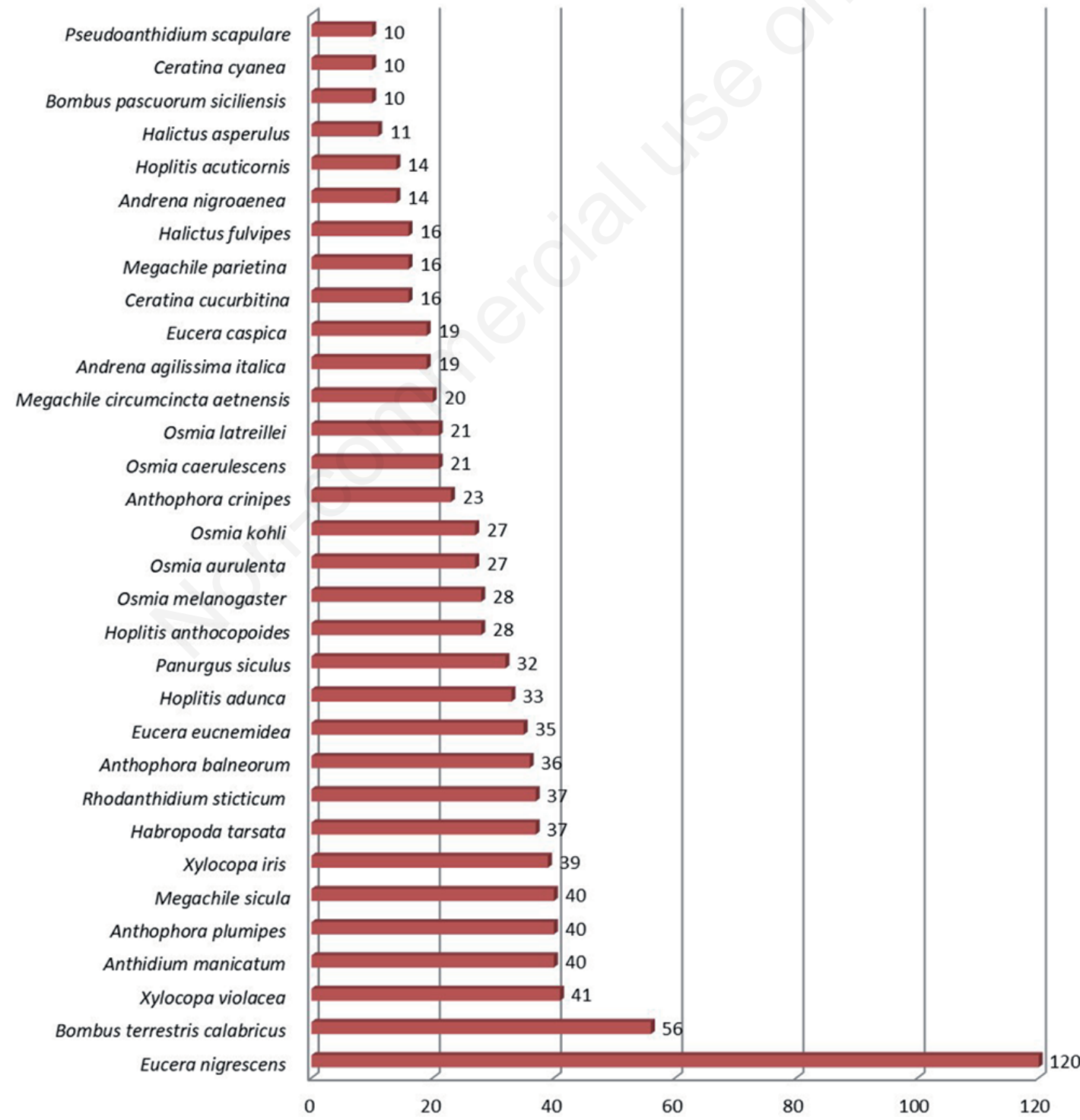

Figure 6. Absolute abundance of species collected in the four selected sites. 
eral urban park (PU) with: Andrenidae (9 species), Apidae (17 spp.), Halictidae (6 spp.), and Megachilidae (21 spp.) (Figure 7D).

The 1140 collected specimens are arranged as follows with regard to sites and families: 1) the agroecosystem (AC) includes 23 specimens of Andrenidae, 8 specimens of Halictidae, 73 specimens of Megachilidae, and 143 specimens of Apidae; 2) the nature reserve (SG), 18 specimens of Andrenidae, 33 specimens of Halictidae, 90 specimens of Megachilidae, and 172 specimens of Apidae; 3) the central urban park (PG), 26 specimens of Andrenidae, 16 specimens of Halictidae, 154 specimens of Megachilidae, and 158 specimens of Apidae; 4) the peripheral urban park (PU), 36 specimens of Andrenidae, 10 specimens of Halictidae, 87 specimens of Megachilidae, and 93 specimens of Apidae (Figure 4).

In detail, Andrena hesperia, A. kamarti, A. limata, A. morio, A. panurgina, Anthophora crassipes, Eucera algira, Nomioides facilis and Stelis nasuta were recorded only for the central urban park (PG), whereas Andrena fumida, Bombus bohemicus, B. maxillosus, Lasioglossum laeve, Megachile albisecta, Osmia notata, O. rufohirta and Xylocopa valga were found only in the peripheral urban park (PU) (Appendix 1). The following species were found in similar variance in both urban parks: Amegilla albigena, Andrena agilissima italica, Hoplitis anthocopoides, Megachile sicula, Osmia aurulenta, O. kohli, O. latreillei, Rhodanthidium sticticum and Xylocopa iris, whereas the following species were more varied: Amegilla albigena, Andrena agilissima italica, Hoplitis anthocopoides, Megachile sicula, Osmia aurulenta, O. kohli, O. latreillei and Rhodanthidium sticticum; these species were not exclusively present in one site or the other one but had differing frequency and abundance between them. In the control

\section{Agroecosystem (AC)}

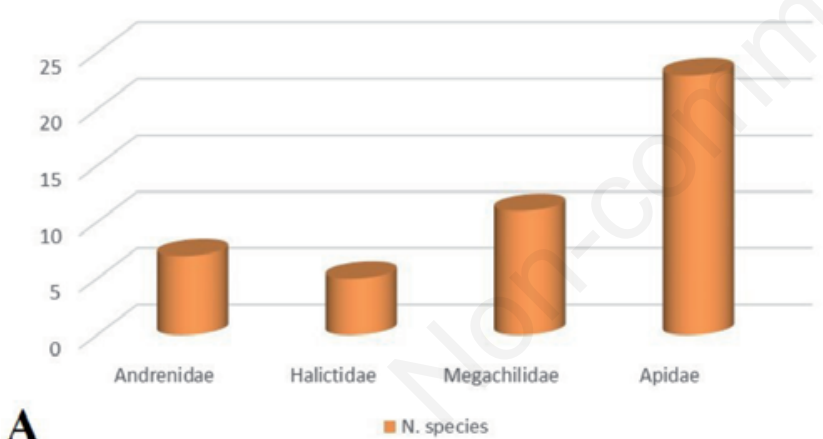

A

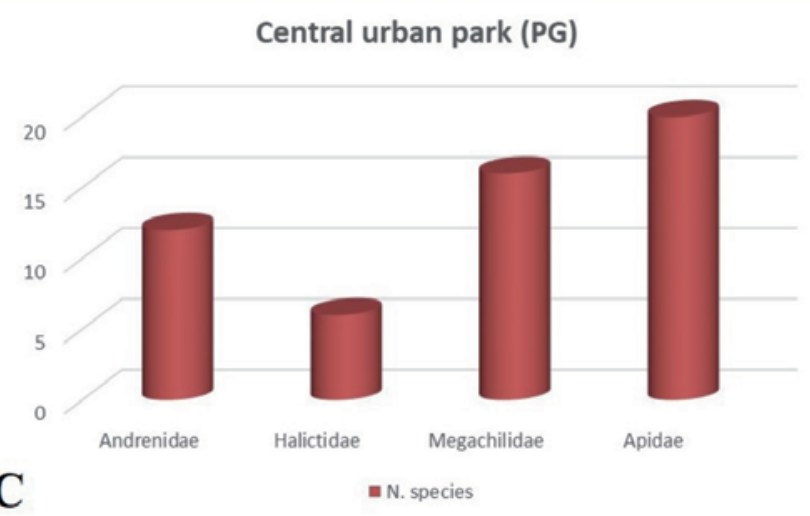

site Leucatia (LE), the bee community included: Colletidae (10 species), Andrenidae (10 spp.), Halictidae (23 spp.), Melittidae (1 sp.), Megachilidae (32 spp.) and Apidae (26 spp.) (Appendix 1). Leucatia's total number of recorded species in this study was 163 , of which 104 were collected in the four investigated sites and 60 exclusively found in Leucatia (LE).

\section{Diversity indexes}

The statistical comparison of the bee communities was based on the different ecological indexes as shown in Figures 8A-C, where the deviances of the values from the average have been highlighted.

The Shannon-Weaver Diversity Index (H') of the investigated sites shows values ranging from 2.0 to 2.5 (Figure $8 \mathrm{~A}$ ); it is higher in the two urban parks, and this indicates a higher diversity. Over the three years, and in the different months, the values of H' do not show significant statistical differences (Figures 8B-D).

The Pielou Evenness Index (J') (Figure 9) and the Simpson Index (SI) (Figure 10) are high in all four investigated sites, with values near to 1.0; these two values are slightly higher in the two urban parks (PG, PU), highlighting a balanced occurrence of species within communities.

During 2009 the agroecosystem (AC) was subjected to mechanical herbaceous removal, and this negatively affected the abundance of bee specimens, albeit not in a significant amount to ecological indexes.

\section{Seasonal patterns}

In terms of species diversity, analyzing the overall data, the bee fauna showed a marked peak in April-May, clearly related to the

Figure 7 (A-D). Bee richness of the four investigated sites; A: Agroecosytem (AC); B: Nature Reserve (SG); C: Central urban park (PG); D: Peripheral park (PU). 
most and abundant presence of flowering plants. The number of species showed a significant reduction in June, and markedly in July-August as flowering plant availability became less abundant (Appendixes 2, 3).

The abundance, in terms of the number of specimens, shows an increase at the beginning of February, with a peak in middle April which remains high until middle June. Abundance then decreases significantly, especially after September (Figure 11). A summary of the seasonal abundance of each species is presented in detail in Appendix 2. The 30 most abundant species are represented by a number of specimens ranging from 10 to 120 .

The most abundant species were Eucera nigrescens and $E$. caspica in March; E. nigrescens, Anthophora balneorum, A. plumipes, Bombus terrestris calabricus and Habropoda tarsata in
A Shannon index $H^{\prime}=-\Sigma\left(P^{*} \log P i\right)$

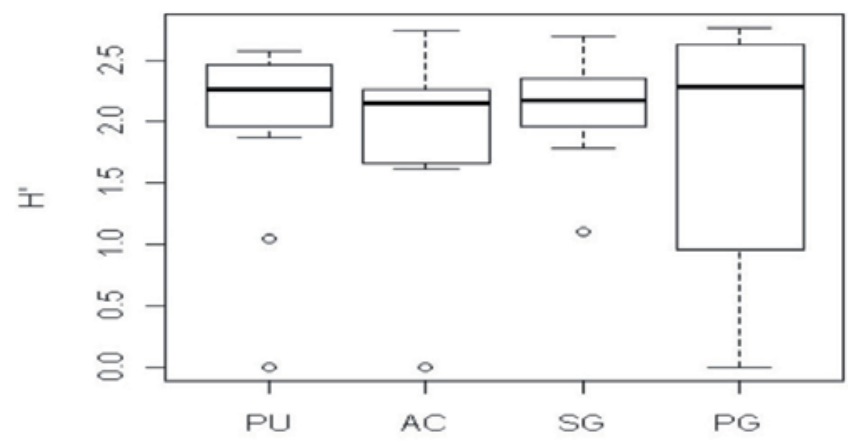

C

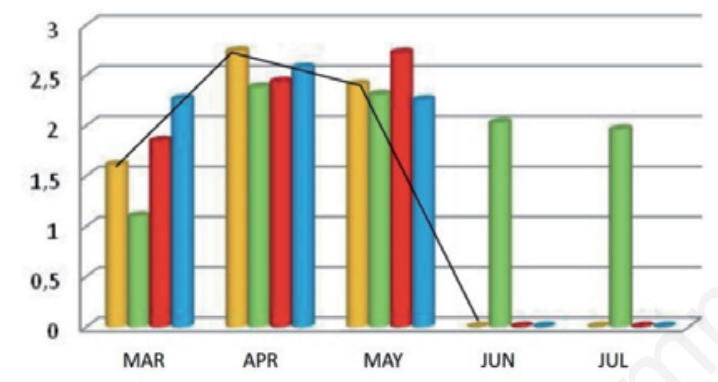

B

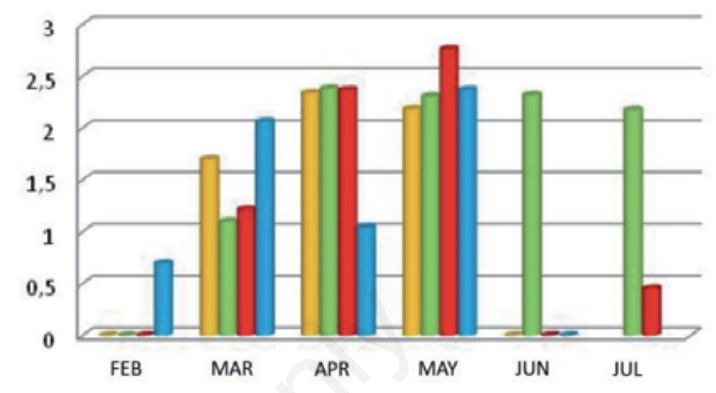

D 2010

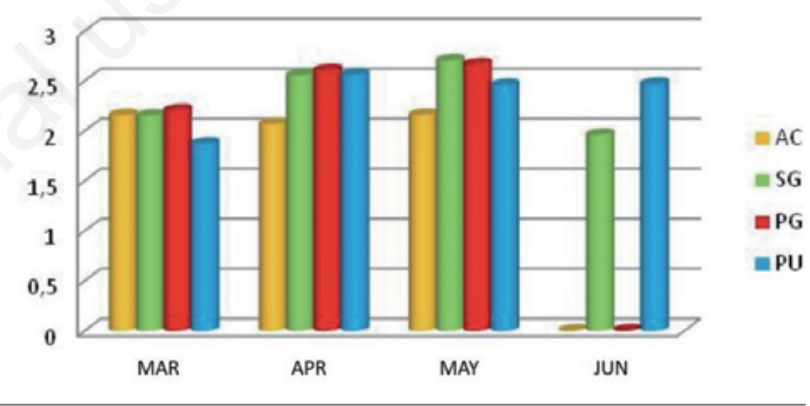

Figure 8 (A-D). A: Shannon-Weaver Diversity Index (H') calculated for the investigated bee communities; Seasonal variation of the Shannon-Weaver Diversity Index (H') calculated for the investigated bee communities for the year 2008 (B), 2009 (C), and 2010 (D).

Pielou's evenness J'=H'/Logs

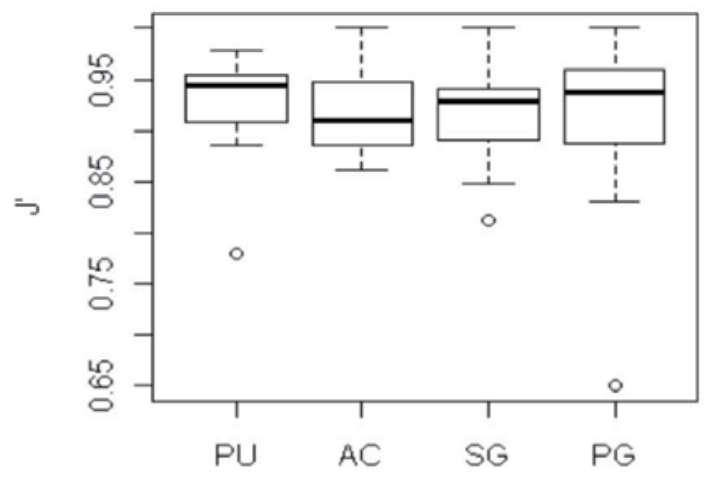

Figure 9. Pielou Evenness Index (J') calculated for the investigated bee communities.
Simpson index $1-\lambda=1-\left(\Sigma p_{1}^{2}\right)$

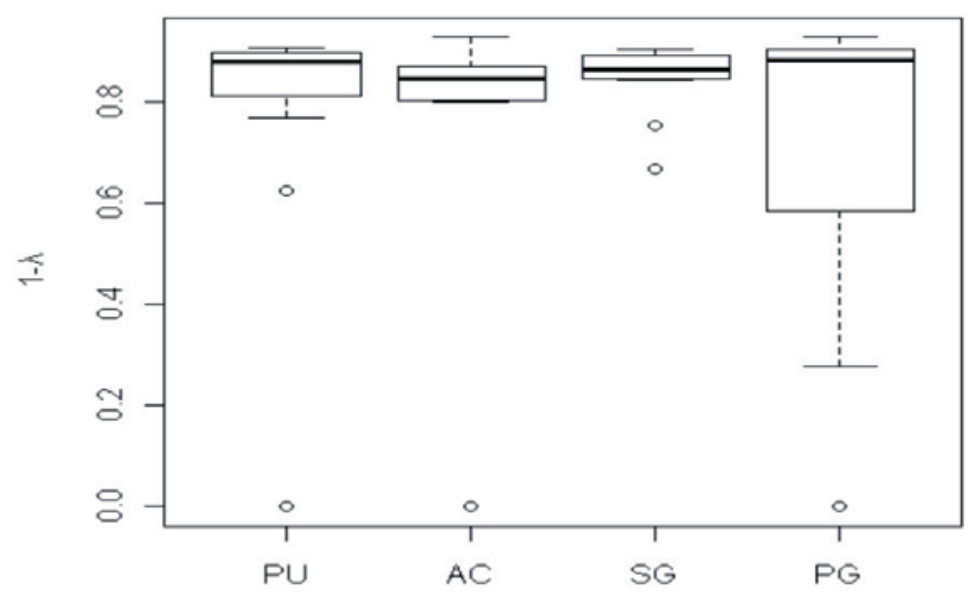

Figure 10. Simpson Index (SI), calculated for the investigated bee communities. 
April-May; Anthidium manicatum, Pseudoanthidium scapulare and Halictus fulvipes in June-August. A separate analysis shows a circadian abundance of bee species for each transect (Appendix 3). Overall, 64 species were recorded at 9:00 (247 specimens), 76 at 12:00 (313 specimens), 58 at 15:00 (354 specimens), and 48 at 18:00 (226 specimens).

\section{Nesting behaviour and floral relationships}

The highest proportion of recorded species was hypogeic (50\%, $52 \mathrm{spp}$.) and this confirms that a variety of suitable and relatively undisturbed substrates were avaliable for bee nesting. A relevant proportion of bees $(40.38 \%, 42 \mathrm{spp}$.) were hypergeic and this confirms that suitable above-ground nesting areas were well represented in the four investigation sites (Appendix 4). Only a few species were nestless $(9.61 \%, 10 \mathrm{spp}$.). With regards to social behavior, "solitary species" were the most prevalent of the recorded bees, with proportions varying from 29.80 to $83.65 \%$ A significant number of bee species (2.88 to $16.34 \%$ ) showed a pre-social behavior, nesting separately in the same place sometimes with a rough division of labor. The social species showed a relatively low proportion with values varying from 2.88 to $17.30 \%$. The parasitic species (CP+PAS) represented $9.61 \%$. The species of genus Bombus are primitively social, and $B$. bohemicus, and B. maxillosus belonging to the subgenus Psithyrus are parasitic (Appendix 4).

The largest proportion of bee species showed a 'long-tongued' buccal apparatus $(66.34 \%)$, whereas the 'short-tongued' species were less represented (33.65\%). In the four investigated sites, the families Apidae and Megachilidae (with 970 specimens and 85\% of the total population), represent the most prevalent proportion of bee communities, mostly having a 'long-tongued' buccal apparatus with the ability to forage a wide variety of trophic floral sources, whereas the 'short-tongued' Halictidae and Andrenidae were significantly less represented.

The results obtained from the nesting trap were too fragmentary for robust, quantitative analysis and comparisons. However, it is noteworthy to point out that from these artificial nests placed in the peripheral urban park (PU), and collected in October 2008, a total of 185 specimens of Osmia latreillei were obtained, 124 males and 61 females (sex ratio: 2.03); they emerged between 17.03.2009 and 28.04.2009. Several specimens of Osmia latreillei's putative parasitoid Sapyga quinquepunctata (Fabricius, 1781) (Hymenoptera, Sapygidae) were obtained as well. This par-

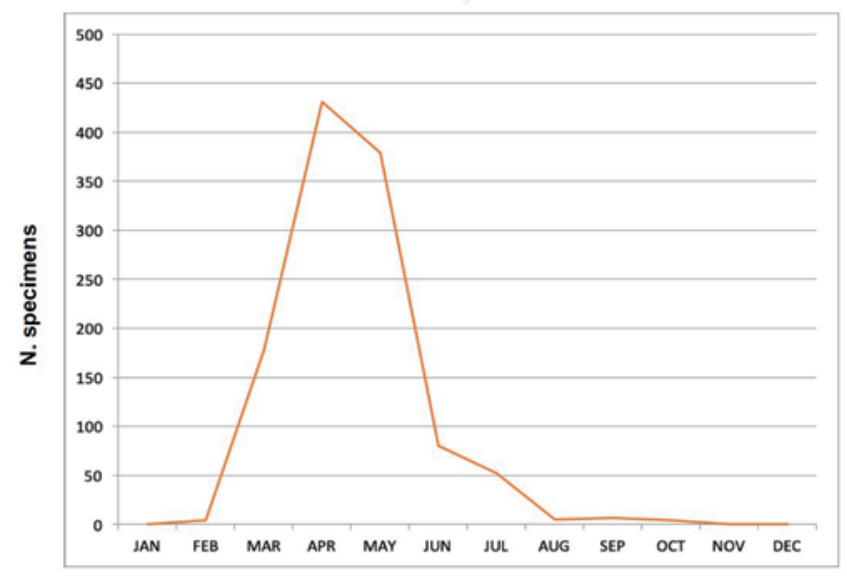

Figure 11. Cumulative seasonal abundance of bees in the four selected sites. asitoid has a circummediterranean distribution and was found within a few localities in Sicily (Turrisi, 1999). It is recorded as a parasitoid of several Colletidae and Megachilidae of the genera Hylaeus, Heriades, Hoplitis, Megachile and Osmia (Ceccolini \& Cianferoni, 2018), but never as a parasitoid of Osmia latreillei.

\section{Discussion}

\section{Characterization of the bee fauna}

Based on the sampling efforts in the four selected sites over three years of research, the areas' bee communities include a total of 104 species (Appendix 1), corresponding to about $15 \%$ of the Sicilian bee fauna (Comba, 2019), and about $25 \%$ of the species known from Volcano Etna (Turrisi \& Turrisi, 2007; Nobile, personal communication). This is a relevant amount of richness within the Sicilian context, especially due to the relatively small size of the investigated sites and the anthropic factors which reduce, in general, diversity and have negative influences on plant diversity and soil suitability. The relatively high richness of the bee communities in the four sites is relevant by comparing the bee diversity with other wider Etnean areas, like the southwest slope of the volcano as highlighted (Turrisi \& Turrisi, 2007).

The bee community at the control site Leucatia (LE), is the richest and most diversified. Analyzing its presence/absence matrix (Appendix 1), the multivariate analysis based on neighborjoining (Jaccard algorithm) shows a low similarity compared with the other four sites appearing quite distinct on dendrogram based on cluster analysis (Figure 12). This is most probably due to the effectively wider area and more diversified habitat, but this is also putatively affected by collection efforts over a longer significant time. The dendrogram also highlights three well-differentiated subgroups highly congruent with affinity predicted by geographic location, area, and vegetational patterns of similar sites, as well as land management regimes. Two subgroups were represented in the nature reserve $(\mathrm{SG})$ and the agroecosystem $(\mathrm{AC})$, whereas the two urban parks formed a quite different cluster (Figure 12). It is very interesting to find the richness and diversity of the bee fauna of the two urban parks, and thus confirms their role in pollinator conservation and biodiversity in general, especially within the dense urban context of Catania, under high anthropic pressure.

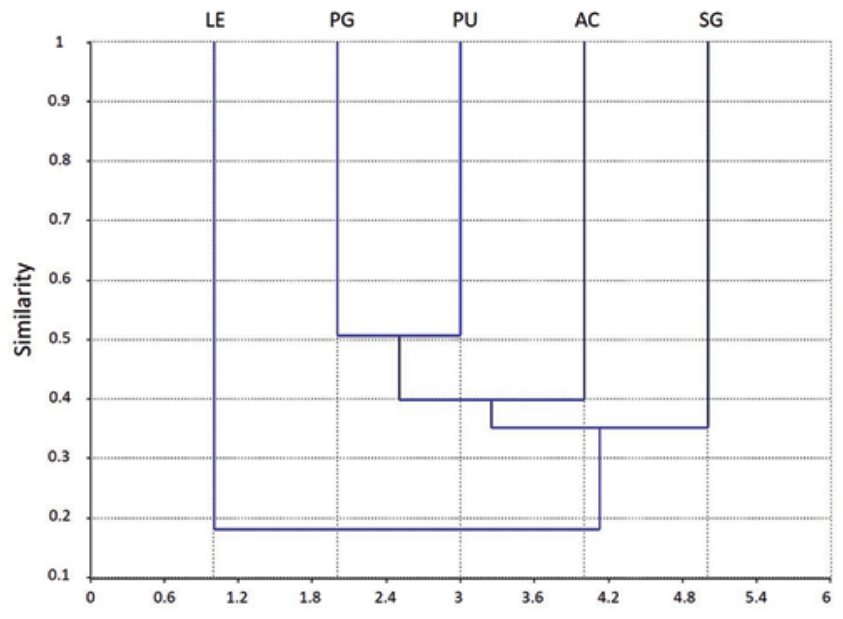

Figure 12. Dendrogram based on cluster-analysis of the five bee communities. 
Most of the recorded species are widely distributed within the Mediterranean basin, but in several cases, there were some with restricted distribution or even endemic, such as Pseudoanthidium gregoriense, known to only a few localities in Eastern Sicily (Nobile, 1989, 1996; Haris \& Józan, 2018). It is remarkable to highlight that Bombus bohemicus, collected at the central urban park (PG), is newly recorded for Sicily.

The most abundant and widespread species in all four sites was Eucera nigrescens, having a wide floral preference and in general a highly plastic ecology.

Our research in the agroecosystem highlights that agricultural practices can seriously affect bee composition and local populations of species. During spring 2009, this site underwent mechanical herbaceous removal although the area's species composition was not seriously influenced. This population resiliency is probably due to two main factors: 1) citrus-orchard flowering has a very long duration period, especially in April-May, entailing adequate trophic resources for most both short-tongued and long-tongued bees and, 2) several significant areas were left safe within the site, thus leaving existing trophic sources unaffected.

\section{Fragmentation and bee communities}

One of the biggest, generally accepted threats claimed to bee communities is habitat fragmentation, which creates a limiting factor for bee population growth (Patiny et al., 2009). The recent current of connectivity conservation pursues the general aim of mitigating the effects of environmental fragmentation on species, communities, ecosystems, and ecological processes by adopting appropriate strategies on territory management (Vuilleumier \& PrélazDroux, 2002; Crooks \& Sanjayan, 2006; Opdam et al., 2006; Selman, 2006; Girvetz et al., 2008). Volcano Etna covers a wide area north of the city of Catania with an extension of about 1250 $\mathrm{km}^{2}$, bordered by the Alcantara Valley to the north, and the Simeto Valley to the west. The south has a wide border with the broad alluvial plain of Catania. These foothill areas have been subjected to pernicious and sometimes dramatic fragmentation due to the effects of the city expansion northward as well as the consequent expansion of many other urban centers along the volcano southern edge. This has caused the loss of significant, natural areas and especially a tremendous and varied assemblage of agroecosystem patches much of which containing citrus orchards (D’Urso et al., 2001).

The expansion of Catania's metropolis is claimed to be the most serious threat against the ecological interconnectivity of all these investigated sites, although to different degrees (Figures 1-2). Biopermeability may be defined as the ability to host and allow the transit of animal and plant species within a certain area (Romano \& Zullo, 2012). The ongoing fragmentation processes around Catania's urban metropolis have created a very complex aggregation of different environmental patches, some completely urbanized (zero to low biopermeability), others cultivated or abandoned, as well as small urban public and private parks (medium to high biopermeability) (La Greca et al., 2011). By analyzing these geographic and ecological contexts (Figures 1-2), it is possible to roughly ascertain the degree of fragmentation and ecological isolation of investigated sites. Both of the two urban parks (PG, PU) occur in densely inhabited areas of Catania with low biopermeability (Figures 1, 2C-D), thus they are more exposed to prevalent microgeographic isolation and ecological threats. Despite their pronounced ecological sensitivity, the two urban parks host relatively rich and diversified bee communities, although with a preponderance of widespread and generalist species. These characteristics can also apply to Leucatia (LE) (Figure 2E), albeit occurring in a significantly urbanized context that is moderately isolated. The nature reserve (SG) occurs in a less fragmented context with a medium- high biopermeability (Figure 2B), although it appears quite isolated along its eastern and northwestern borders. The agroecosystem (AC) occurs in a low to moderate fragmented context with a medium to high connectivity around its borders, especially due to the presence of traditional citrus-orchards having a medium to good biopermeability (D’Urso et al., 2001; Ciaccia et al., 2019).

An important ecological trait of bees is represented by the disjunction of the foraging area and the nesting site (Westrich, 1996; Lundberg \& Moberg, 2003; Oertli et al., 2005). Most bees have specific nesting preferences, such as dead wood, bare soil, plant stems, or rock fissures. As bees are typical central-place foragers, who return to their nests after foraging, feeding and nesting sites must be nearby one another. These circumstances are a manifest weakness for their ecology. In general, the investigated sites host both a significant availability of foraging areas and nesting sites, closely placed within. The relatively rich and diversified bee communities of these sites that are located close to each other. The relatively rich and diversified bee communities of these sites have undoubtedly been affected by changes over time, and most of the recorded species were generalists in regard to flowering plants and nesting preferences.

\section{Conclusions}

The results obtained over a three-year study of four selected bee communities, and a long-term investigation in the control site at Leucatia, highlight the richness and diversification of bee communities even in a highly fragmented territory like the southeastern slope of Volcano Etna, the wide urban area of Catania city.

The amount of parasitic (CP+PAS) bees observed in our investigation over the total of species is $9.61 \%$. This is considered as a significant finding to evaluate this local bee community, as the diversity and abundance of cleptoparasites in relation to all bees is indicative of their community's ecological state and monitoring them should form an integral part of assessing bee communities. They represent the apex of bee communities and are the first guild to respond to disturbances and play a stablizing role within bee communities (Sheffield et al., 2013).

Our research confirms the most important threats outlined by Patiny et al. (2009) affecting bee communities in Europe, such as fragmentation, presence of physical barriers, diversity of flowering plants, use of biocides, and invasive species. Of the abovementioned species, all threats excluding the latter could be fully applied to the bee communities studied on the southeastern slope of Etna.

The results clearly show that the seasonal maximum of activity for foraging and nesting is mainly during March-May and into June. Especially in urban parks and agroecosystems, it is crucial for bee conservation to avoid practices that reduce herbaceous flowering during that period, either by mechanical removal or chemical treatments. Another threat affecting the peripheral urban park (PU) is the negative impact of frequent fires, which dramatically reduce its trophic resources. The maintenance of suitable nesting sites is crucial for the conservation of bee communities, and this can be done effectively by reserving several designated, undisturbed areas within the site. This is particularly necessary for urban parks and agroecosystems. The maintenance of undisturbed marginal areas with a good floral variety and suitable nesting sites have been proven to be the best practices for enhancing bee communities in Europe (Le Féon et al., 2010).

Our findings show that bees are crucial faunal components whose composition and dynamism allow observers to evaluate: i) 
the rough degree of the location's reactions to environmental changes (e.g., mechanical removal of the herbaceous layer); ii) the identification of the most ecologically significant habitats within an environmental context; iii) the relevant ecological roles of marginal abandoned areas for biodiversity purposes, specifically for bee communities; iv) the overturning of conventional environmental planning concepts taking that does not take into account biodiversity conservation; v) a resolution's scale of improvement, at the microgeographic level, to understand the efficacy of an ecological network.

Marginal areas such as abandoned cultivations, urban parks, and traditional agroecosystems, together with already protected areas like the Complesso Immacolatelle Nature Reserve, play an important role as nodal areas. However, this is not enough to create a healthier ecological network without attending to the many other currently unprotected areas which are under further fragmentation or destruction due to urbanization (Turrisi et al., 2006; La Greca et al., 2011).

As widely confirmed by literature (Tommasi et al., 2004; Hennig \& Ghazoul, 2011; Wilson \& Jamieson, 2019), the negative ecological effects of fragmentation could be mitigated by enhancing floral sources and inter-connectivity through environmental patches, of which urban and private parks could play a significant role in creating thriving bee communities (Tommasi et al., 2004). As confirmed by this research, and by other recent studies in different geographical contexts, marginal areas and urban settings can contribute significantly to the conservation of bee communities (Rollin et al., 2015; Sirohi et al., 2015).

\section{References}

BANASZAK J., 1995 - Natural resource of wild bees in Poland and an attempt at estimation of their changes. In Banaszak J. Changes in Fauna of wild bees in Europe, Bydgoszcz, Pedagogical University: 127-146.

BELLA S., CATANIA R., NOBILE V., MAZZEO G., 2020 - New or little known bees (Hymenoptera, Apoidea) from Sicily. Fragm Entomol 52: 113-117.

BELLA S., MUSMECI M., 2004 - Catania Verde: un modo diverso per conoscere la città. Cavallotto Edizioni: 48 pp.

BROOKS R.W., 1988 - Systematics and Phylogeny of the Anthophorine Bees (Hymenoptera: Anthophoridae; Anthophorini). - The University of Kansas Science Bulletin, 53: 436-575.

BROWN M.J.F., PAXTON R.J., 2009 - The conservation of bees: a global perspective. - Apidologie, 40: 410-416.

CECCOLINI F., CIANFERONI F., 2018 - Review of the distribution of Sapygidae in Italy and new records (Hymenoptera: Vespoidea). - Fragmenta entomologica, 50: 111-115.

CIACCIA C., LA TORRE A., FERLITO F., TESTANI E., BATTAGLIA V., SALVATI L., ROCCUZZO G., 2019 Agroecological practices and agrobiodiversity: a case study on organic orange in southern Italy. - Agronomy, 9 (85): 2-13. DOI:10.3390/agronomy9020085.

COMBA M., 2019 - Hymenoptera Apoidea: Anthophila of Italy. Available from: http: //digilander.libero.it/mario.comba. [accessed 7 Sept. 2021].

CORBET S.A., WILLIAMS I.H., OSBORNE J.L., 1991 - Bees and the pollination of crops and wild flowers in the European Community. - Bee World, 72: 47-59.

CROOKS, K.R., SANJAYAN, M.A., 2006 - Connectivity Conservation: Maintaining Connections for Nature. In:
Crooks, K.R. and Sanjayan, M., Eds.: Connectivity Conservation, Cambridge University Press, Cambridge, 1-20.

DOBSON A., RALLS K., FOSTER M., SOULÉ M.E., SIMBERLOFF D., DOAK D., ESTES J.A., MILLS L.S., MATTSON D., DIRZO R., ARITA H., RYAN S., NORSE E.A., NOSS R.F., JOHNS D., 1999 - Corridors: reconnecting fragmented landscapes. In: Soulé M.E., Terborgh J. (eds.). Continental Conservation. The Wildland Project. Island press, Washington D.C.: 129-170.

DUELLI P., OBRIST M.K., 1998 - In search for the best correlates for local organismal biodiversity in cultivated areas. Biodiversisty Conservation, 7: 297-309.

D'URSO V., SIRACUSA G., LICCIARDELLO G., TOMASELLI G., 2001 - Il ruolo degli agrumeti etnei e dei manufatti edilizi connessi nella costruzione delle reti ecologiche periurbane. La biodiversità nei paesaggi agrari e forestali. - Collana Siciliana Foreste, 15: 99-126.

EBMER A.W., 1974 - Die Bienen des Genus Halictus Latr. s.l. im Großraum von Linz. (Hymenoptera, Apidae). - Nat. Jahrb. der Stadt Linz, 19: 123-158.

ERBAR C., LEINS P., 2017 - Sex and breeding behaviour of the Sicilian snail-shell bee (Rhodanthidium siculum Spinola, 1838; Apoidea-Megachilidae): preliminary results. - ArthropodPlant Interactions, 11 (3): 317-328. DOI 10.1007/s11829-0169489-x.

GIRVETZ E.H., THORNE J.H., BERRY A.M., JAEGER J.A.G., 2008 - Integration of landscape fragmentation analysis into regional planning: A statewide multi-scale case study from California, USA. - Landscape and Urban Planning, 86: 205-218.

HAMMER O., HARPER D.A.T., RYAN P.D. 2001 - Past: Paleontological statistics software package for education and data analysis. - Palaeontologia Electronica, available at: http://palaeo-electronica.org.

HANSKI I., 1999 - Habitat connectivity, habitat continuity, and metapopulation in dynamic landscapes. - Oikos, 87: 209-219.

HARIS A., JÓZAN Z., 2018 - Data to the Hymenoptera fauna of Sicily (Hymenoptera: Symphyta and Aculeata). - Natura Somogyiensis, 31: 63-76.

HENLE K., DAVIES K.F., KLEYER M., MARGULES C., SETTELE J., 2004 - Predictors of species sensitivity to fragmentation. - Biodiversity and Conservation, 13: 207-251.

HENNIG E.I., GHAZOUL J., 2011 - Pollinating animals in the urban environment. - Urban Ecosystems, 15: 149-166.

HERNANDEZ J.L., FRANKIE G.W., THORP R.W., 2009 Ecology of Urban Bees: A Review of Current Knowledge and Directions for Future Study. - Cities and the environment, 2: $1-15$.

INTOPPA F., PIAZZA M.G., BOLCHI SERINI G., CORNALBA M., 2009 - I Bombi, Guida al riconoscimento delle specie italiane. CRA - Unità di Ricerca di Apicoltura e Bachicoltura.

LA GRECA P., 2010 - Diversità ed ecologia degli Imenotteri Apoidei in ambienti frammentati pedemontani dell'Etna a differente pressione antropica. Dottorato di Ricerca in "Scienze Entomologiche e difesa degli agroecosistemi". XXIII ciclo. Anno Accademico 2007-2010, Università degli Studi di Catania.

LA GRECA P., NOBILE V., D’URSO V., TURRISI G.F., 2011 Diversità ed ecologia degli Imenotteri Apoidei in ambienti frammentati pedemontani dell'Etna a differente pressione antropica. Congresso Nazionale Italiano di Entomologia, Genova, 13-16 giugno 2011.

LE FÉON V.L., SCHERMANN-LEGIONNET A., DELETTRE Y., AVIRON S., BILLETER R., BUGTER R.J.F., HENDRICKX F., BUREL F., 2010 - Intensification of agriculture, landscape 
composition and wild bee communities: a large scale study in four European countries. - Agriculture, Ecosystems \& Environonment, 137: 143-150.

LEVERMANN E.M., BISCHOFF I., WAGNER T., 2000 - Speciesspecific foraging strategies of the syntopical and synchronous bees Panurgus calcaratus (Scopoli, 1763) and Dasypoda hirtipes (Fabricius, 1793). - Beitrage Ent., 50: 179-191.

LONGO S., 2002 - Ruolo degli agroecosistemi nella conservazione della biodiversità. - Tecnica Agricola, 3-4: 73-79.

LUNDBERG J., MOBERG E., 2003 - Mobile link organisms and ecosystem functioning: implications for ecosystem resilience and management. - Ecosystems, 6: 87-98.

MAGURRAN A.E., 2004 - Measuring biological diversity. Blackwell publishing. Oxford, UK.

MATHESON A., BUCHMANN S.L., O'TOOLE C., WESTRICH P., WILLIAMS I.H. eds., 1996 - The conservation Biology of bees. London Academic Press: 252 pp.

MAZZEO G., LONGO S., BELLA S., 1999 - Il censimento dei pronubi in Sicilia. Tecnica Agricola, 4: 67-75.

MAZZEO G., LONGO S., PALMERI V., BELLA S., 2001 Anthophilous insect indicating biodiversity in natural and cultivated sicilian environments. - Insect Social Life, 4: 93-100.

MAZZEO G., LONGO S., BELLA S., 2002 - I pronubi rivelati su colture minori in Sicilia orientale. Atti XIX Congresso Nazionale di Entomologia, Catania 10-15 giugno: 1275-1280.

MAZZEO G., LONGO S., PALMERI V., SEMINARA A., BELLA S., ZAPPALÀ L., 2004 - Anthophilous insect in fruit orchards on Mount Etna (Italy). - Redia, 88: 247-251.

MAZZEO G., LONGO S., SEMINARA A., BELLA S., FERRAUTO G., 2007a. Prelimirary observations on anthophilous insect and foraging behaviour of Apis mellifera L. in a protected area of the Etna park. - Redia, 90: 109-113.

MAZZEO G., SEMINARA A., BELLA S., FERRAUTO G., LONGO S., 2007b. Osservazioni sugli apoidei e sull'attività di Apis mellifera L. in un'area alto montana del Parco dell'Etna. - Apoidea, 4: 163-168.

MAZZEO G., BELLA S., SEMINARA A.R., LONGO S., 2015 Bumblebees in natural and agro-ecosystems at different altitudes from Mount Etna, Sicily (Hymenoptera Apidae Bombinae): long-term faunistic and ecological observations. Redia, XCVIII: 123-131.

MAZZEO G., LONGO S., SEMINARA A.R., BELLA S., 2019 Faunistic and ecological studies on Apidae (Hymenoptera, Apoidea) in natural and cultivated ecosystems in Sicily. Redia, 102: 153-162.

MICHENER C.D., 2007 - The bees of the world. The John Hopkins University Press. Baltimore: XVI +953 pp.

MÜLLER A., 2019 - Palaearctic Osmiine Bees, ETH Zürich. http://blogs.ethz.ch/osmiini.

NICOLI ALDINI R., 1994 - Preliminary observation on gregarious sleeping in Amegilla (s. str.) garrula (Rossi) (Hymenoptera Apoidea Anthophoridae). - Ethology Ecology \& Evolution, 6: 131-135.

NICOLI ALDINI R., 2007 - Etologia degli Apoidei presociali (Hymenoptera Apoidea). - APOidea, 4: 150-162.

NOBILE V., 1987 - Contributo alla conoscenza degli Apoidei (Insecta, Hymenoptera) di Sicilia. I. I generi Habropoda Smith, Tetralonia Spinola (gruppo ruficornis F.), Melecta Latreille, Eupavlovskia Popov e Thyreus Panzer. - Animalia, 14: 73-89.

NOBILE V., 1988 - Contributo alla conoscenza degli Apoidei (Insecta, Hymenoptera) di Sicilia. II. Il genere Osmia Panzer 1806. - Animalia, 15: 159-173.

NOBILE V., 1989 - Il genere Anthidium Fabricius 1804 e affini (Hymenoptera, Apoidea, Megachilidae) in Sicilia, con descrizione di Pseudoanthidium alpinum gregoriense subsp. n. - Animalia, 16: 131-145.

NOBILE V., 1990 - Contributo alla conoscenza delle Api parassite (Insecta Hymenoptera) di Sicilia. II. Il genere Nomada Scopoli 1770, con descrizione di una nuova specie. - Animalia, 17: 219-243.

NOBILE V., 1991 - Contributo alla conoscenza delle Api solitarie (Insecta, Hymenoptera) di Sicilia. IV. La tribù Anthophorini Dahlbom 1835. - Animalia, 18: 237-259.

NOBILE V., 1993 - La piccola Ape di Vendicari. - Grifone, Ente Fauna Siciliana, 2: 2.

NOBILE V., 1993b - Endemismi di Sicilia. Tetralonia alticincta bindai, nuova sottospecie di Imenottero Apoideo. - Atti e Memorie, suppl. Grifone, Ente Fauna Siciliana, 1: 95-98.

NOBILE V., 1994 - Contributo alla conoscenza di alcune Api solitarie (Hymenoptera, Halictidae Duforeinae) di Sicilia. V. Il genere Rophitoides Schenck 1859, con descrizione di un nuovo taxon. - Animalia, 20 (1993): 59-63.

NOBILE V., 1995a - The apidological situation in Sicily, with remarks on the phenomenon of endemism. Changes in Fauna of Wild Bees in Europe, Jòsef Banaszak (ed.), Pedagogical Univ. Bydgoszcz, Poland: 127-146.

NOBILE V., 1995b - Ricordo di Teodosio De Stefani-Perez a 100 anni dalla pubblicazione del suo "Catalogo degli Imenotteri di Sicilia", con dedica di una nuova specie di Imenottero Apoideo. - Grifone, Ente Fauna Siciliana, 4: 4-5.

NOBILE V., 1996 - Api (Insecta Hymenoptera) nuove o poco note di Sicilia e di Sardegna. - Bollettino dell'Accademia Gioenia di Scienze Naturali, 28 (1995): 147-159.

NOBILE V., 2001 - Le Andrene W-paleartiche con due celle cubitali (Hymenoptera, Apoidea, Andrenidae) con descrizione di Parandrena iohannescaroli sp. n. - Bollettino dell'Accademia Gioenia di Scienze Naturali, 33 (2000): 35-42.

NOBILE V., CAMPADELLI G., 1998 - Il genere Sphecodes Latreille 1804 in Italia (Hymenoptera, Apoidea, Halictidae). Bollettino dell'Istituto di Entomologia "G. Grandi" Univ. Bologna, 52: 85-103.

NOBILE V., TOMARCHIO S., 1998 - Contributo alla conoscenza degli Apoidei di Sicilia. XIV. La famiglia Melittidae (Insecta, Hymenoptera). - Bollettino dell'Accademia Gioenia di Scienze Naturali, 30 (1997): 285-290.

NOBILE V., TOMARCHIO S., 1998b - Contributo alla conoscenza degli Apoidei di Sicilia. XV. Il genere Spatulariella Popov 1939 (Hymenoptera, Colletidae, Hylaeinae) con descrizione di una nuova specie. - Bollettino dell'Accademia Gioenia di Scienze Naturali, 30 (1997): 291-298.

NOBILE V., TOMARCHIO S., 2001 - Apoidei nuovi o poco noti di alcune regioni d'Italia (Hymenoptera, Apoidea, Megachilidae). - Bollettino dell'Accademia Gioenia di Scienze Naturali, 33 (2000): 43-54.

NOBILE V., TURRISI G.F., 1997 - Contributo alla conoscenza degli Apoidei di Sicilia. I. Le tribù Lithurgini, Dioxyni e Stelidini (Insecta, Hymenoptera, Megachilidae). - Bollettino dell'Accademia Gioenia di Scienze Naturali, 29 (1996): 15-26.

NOBILE V., TURRISI G.F., 1999 - Contributo alla conoscenza degli Apoidei cleptoparassiti di Sicilia. IV. La tribù Coelioxyni (Hymenoptera, Apoidea, Megachilidae). - Bollettino dell'Accademia Gioenia di Scienze Naturali, 32: 161-170.

NOBILE V., TURRISI G.F., 2004. Contribution to the knowledge of Italian cleptoparasitic Bees. X. The genus Sphecodes Latreille, "pinguiculus Pérez" group with description of new species (Hymenoptera, Apoidea, Halictidae). - Entomofauna, Zeitschrift für Entomologie, 25: 117-132.

NOBILE V., TURRISI G.F., 2013 - Remarks on the genus 
Sphecodes Latreille, 1804, pinguiculus Pérez, 1903 speciesgroup (Hymenoptera Apidae) from Italy: a reply to the article of Schwarz \& Gusenleitner (2012). - Biodiversity Journal, 4: 565-570.

NOBILE V., TURRISI G.F., 2015 - New or little known Halictidae from Italy (Hymenoptera Apoidea). - Bollettino della Società Entomologica Italiana, 147: 39-42.

NOBILE V., TURRISI G.F., 2016 - New or little known Nomada Scopoli from Italy (Hymenoptera, Apoidea, Apidae). Bollettino della Società Entomologica Italiana, 148: 51-55.

OERTLI S., MÜLLER A., DORN S., 2005 - Ecological and seasonal patterns in the diversity of a species-rich bee assemblage (Hymenoptera: Apoidea: Apiformes). - European Journal of Entomology, 102: 53-63.

OPDAM P., STEINGRÖVER E., VAN ROOIJ S., 2006 Ecological networks: A spatial concept for multi-actor planning of sustainable landscapes. - Landscape and Urban Planning, 75: 322-332.

ORR M.C., HUGHES A.C., CHESTERS D., PICKERING J., ZHU C.-D., ASCHER J.S., 2020 - Global patterns and drivers of bee distribution. - Current Biology 31: 1-8.

PATINY S., RASMONT P., MICHEZ D., 2009 - A survey and review of the status of wild bees in the West-Palaearctic region. - Apidologie, 40: 313-331.

PESENKO Y.A., BANASZAK J., RADCHENKO V.G., CIERZNIAK T., 2000 - Bees of the family Halictidae (excluding Sphecodes) of Poland: taxonomy, ecology, bionomics. Bydgoszcz 2000.

PIELOU E.C., 1984 - The interpretation of ecological data. A primer on classification and ordination. John Wiley \& Sons, New York, 263 pp.

PORRINI C., RADEGHIERI P., ROMAGNOLI F., VERSARI S., 1998 - I pronubi selvatici come indicatori della biocomplessità ambientale. Atti XVII Congr. Naz. it. Ent., Maratea 21-26 giugno 1998.

PRENDERGAST K.S., MENZ M.H.M., DIXON K.W., BATEMAN P.W., 2020 - The relative performance of sampling methods for native bees: an empirical test and review of the literature. - Ecosphere 11: 1-22.

QUARANTA M., AMBROSELLI S., BARRO P., BELLA S., CARINI A., CELLI G., COGOI P., COMBA L., COMOLI R., FELICIOLI A., FLORIS I., INTOPPA F., LONGO S., MAINI S., MANINO A., MAZZEO G., MEDRZYCKI P., NARDI E., NICCOLINI L., PALMIERI N., PATETTA A., PIATTI C., PIAZZA M. G., PINZAUTI M., PORPORATO M., PORRINI C., RICCIARDELLI D'ALBORE G., ROMAGNOLI F., RUIU L., SATTA A., ZANDIGIACOMO P., 2004 - Wild bees in agroecosystems and semi-natural landscapes. - Bulletin of Insectology, 57: 11-61.

ROBINSON R.A., SUTHERLAND W.J. 2002 - Post-war changes in arable farming and biodiversity in Great Britain. - Journal of Applied Ecology, 39: 139-176.

ROLLIN O., BRETAGNOLLE V., FORTEL L., GUILBAUD L., HENRY M., 2015 - Habitat, spatial and temporal drivers of diversity patterns in a wild bee assemblage. - Biodiversity Conservation, 24: 1195-1214.

ROMANO B., ZULLO F., 2012 - Landscape fragmentation in Italy. Indices implementation to support territorial policies. In: Campagna M., De Montis A., Isola F., Lai S., Pira C., Zoppi C. (Eds), Planning Support Tools: policy analysis, implementation and evaluation. Proceedings of the Seventh International Conference of Informatics and Urban and Regional Planning INPUT 2012. Franco Angeli: 399-414.

SCHEUCHL E., 2000 - Illustrierte Bestimmungstabellen der
Wildbienen Deutschlands und Österreichs. Band I: Anthophoridae. 2. Erweiterte Auflage; Eigenverlag: Berlin, Germany, pp. 158.

SCHEUCHL E., 2006 - Illustrierte Bestimmungstabellen der Wildbienen Deutschlands Und Österreichs für Osmia s.1. unter Berücksichtigung der Arten der Schweiz, Norditaliens, Ungarns, Sloweniens und der Slowakei. Band II, Schlüssel der Arten der Familien Megachilidae und Melittidae, 2nd ed.; Apollo books: Tsim Sha Tsui, Japan, pp. 192.

SCHMID-EGGER C., SCHEUCHL E., 1997 - Illustrierte Bestimmungstabellen der Wildbienen Deutschlands und Österreichs unter Berücksichtigung der Arten der Schweiz. Band III; Andrenidae: Eigenverlag, Velden, 180 Seiten.

SELMAN P., 2006 - Planning at the landscape scale. Routledge, Abingdon, United Kingdom, 224 pp.

SEMINARA A., BELLA S., MAZZEO G., LONGO S., 2009 Risultati di un triennio di studi sugli insetti antofili in un biotopo del vulcano Etna. - Apoidea, 6: 27-35.

SIROHI M.H., JACKSON J., EDWARDS M., OLLERTON J., 2015 - Diversity and abundance of solitary and primitively eusocial bees in an urban centre: a case study from Northampton (England). - Journal of Insect Conservation, 19: 487-500.

SHEFFIELD C.S., PINDAR A., PACKER L., KEVAN P.G., 2013 - The potential of cleptoparasitic bees as indicator taxa for assessing bee communities. - Apidologie, 44: 501-510.

STEFFAN-DEWENTER, I. 2002 - Landscape context affects trap nesting bees, wasps, and their natural enemies. - Ecological Entomology, 27: 631-637.

STEFFAN-DEWENTER I., 2003 - Importance of habitat area and landscape context for species richness of bees and wasps in fragmented orchard meadows. - Conservation Biology, 17: 1036-1044.

STEFFAN-DEWENTER I., KEIN A.-M., GAEBELE V., ALFERT T., TSCHARNTKE T., 2006 - Bee diversity and plant-pollinator interactions in fragmented landscapes. In: Plant-pollinator interactions, from specialization to generalization, Waser N.M. \& Ollerton J. (Eds.), The University of Chicago Press: 387-407.

STEFFAN-DEWENTER I., LESCHKE K., 2003 - Effects of habitat management on vegetation and above-ground nesting bees and wasps of orchard meadows in Central Europe. Biodiversity \& Conservation, 12: 1953-1968.

STEFFAN-DEWENTER I., MÜNZENBERG U., BÜRGER C., THIES C., TSCHARNTKE T., 2002 - Scale-dependent effects of landscape context on three pollinator guilds. - Ecology, 83: 1421-1432.

TERAYAMA M., MURATA K., 1990 - Effects of area fragmentation of forests for nature conservation: analysis by ant communities. - Bulletin of Biogeographical Society of Japan, 45: 11-17.

TERZO M., RASMONT P., 2011 - Atlas of the European Bees: genus Ceratina. STEP Project, Atlas Hymenoptera, Mons, Gembloux. http://www.zoologie.umh.ac.be/hymenoptera/page. asp?ID=192.

TOMMASI D., MIRO A., HIGO H.A., WINSTON M.L., 2004 Bee diversity and abundance in an urban setting. - The Canadian Entomologist, 136: 851-869.

TSCHARNTKE T., GATHMANN A., STEFFAN-DEWENTER I., 1998 - Bioindication Using Trap-Nesting Bees and Wasps and Their Natural Enemies: Community Structure and Interactions. - Journal of Applied Ecology, 35: 708-719.

TURRISI G.F., 1999 - La famiglia Sapygidae in Sicilia (Hymenoptera Scolioidea). - Bollettino dell'Accademia Gioenia di Scienze Naturali, 31: 335-338. 
TURRISI G.F., TURRISI R.E., 2007 - Biodiversità degli Imenotteri (Insecta, Hymenoptera) del Giardino Botanico "Nuova Gussonea" e delle aree limitrofe (Sicilia, Etna): un contributo preliminare. In: Atti del Convegno "Conservazione della biodiversità negli Orti Botanici e nei Giardini Alpini e di montagna", Nicolosi (Catania), Monastero dei Benedettini, Parco dell'Etna, 1-2 giugno 2005. - Bollettino dell'Accademia Gioenia di Scienze Naturali, 40: 103-140.

TURRISI R.E., BELLA S., TURRISI G.F., 2006 - Aspetti naturalistici dell'area di Monte Ciraulo (Sicilia, Etna: Mascalucia) ed importanza della loro conservazione. In: Arcidiacono S., Petralia A., Sperlinga G. (Eds.), "La tutela dell'ambiente nel territorio catanese: stato, problemi, prospettive". Atti del Forum delle Associazioni Ambientaliste della provincia di Catania, Catania, 22 maggio 2004, Dipartimento di Biologia Animale "Marcello La Greca". Nuova ZangaraStampa Editrice: $157-168$.

VICIDOMINI S., 1995 - Biologia di Xylocopa (Xylocopa) violacea (L., 1758): specie di fiori visitate dalla femmina (Hymenoptera: Apidae). - Entomologica, 29: 199-214.

VUILLEUMIER S., PRÉLAZ-DROUX R., 2002 - Map of ecological networks for landscape planning. - Landscape and Urban Planning, 58: 157-170.

WCISLO W.T., CANE J.H., 1996 - Floral resource utilization by solitary bees (Hymenoptera: Apoidea) and exploitation of their stored foods by natural enemies. - Annual Review of Entomology, 41: 257-286.

WESTPHAL C., BOMMARCO R., CARRÉ G., LAMBORN E., MORISON N., PETANIDOU T., POTTS S.G., ROBERTS S.P.M., SZENTGYÖRGYI H., TSCHEULIN T., VAISSIÈRE B.E., WOYCIECHOWSKI M., BIESMEIJER J.C., KUNIN W.E., SETTELE J., STEFFAN-DEWENTER I., 2008 Measuring bee diversity in different European habitats and biogeographical regions. - Ecological Monographs, 78: 653-671.

WESTRICH P., 1990 - Die wildbienen Baden-Wüttembergs. Ulmer Verlag, Stuttgart, 1, 2: 972 pp.

WESTRICH P., 1996 - Habitat requirements of central European bees and the problems of partial habitats. In: Matheson A., Buchmann S.L., O’Toole C., Westrich P. \& Williams I.H. (eds): The Conservation of Bees. Academic Press, London, 16 pp.

WILCOVE D.S., MCLELLAN C.H., DOBSON A.P., 1986 Habitat fragmentation in the temperate zones. In: Soulé M.E. (ed.). Conservation Biology. Sinauer Associates Inc. Sunderland, Massachusetts: 237-256.

WILSON C.J., JAMIESON M.A., 2019 - The effects of urbanization on bee communities depends on floral resource availability and bee functional traits. - PLoS One 14: 1-18.

WINFREE R., AGUILAR R., VAZQUEZ D.P., LE BUHN G., AIZEN M., 2009 - A meta-analysis of bees' responses to anthropogenic disturbance. - Ecology, 90: 2068-2076. 